containing it did exist, some of them very ancient and splendid copies. It says a great deal for Ubertino's intelligence that he noted this reading together with other peculiarities of the old codex, and that then he had a reference to it ready when he wanted it many years later. His statement about the 'old codex which he reports oculata fide is credible to the specialist now, more credible than it must have seemed to Papini about 1820 or to the Papal Court at Avignon in I3I I, and therefore it seems, reasonable to believe his statement about Brother Leo's rotuli, which he also claims to have seen.

- As for the degree of accuracy to which Ubertino attains, we may note that his quotation from Matt. xxvii drops a certain number of words and clauses per incuriam. . Thas' the old codex no doubt had dicens before helii, and ex eis before currens unus, and it almost certainly did not omit after bibere the clause Ceteri uero dicebant sine uideamus an ueniat Elias liberans eum. Probably also it read aqua et sanguis, with all the authorities except Gat. But these things do not affect the main issue, which is that Ubertino is not romancing, but giving an intelligent and intelligible account of something that be had really seen. The only thing that remains with me as a permanent surprise is that this champion of the strictest poverty should have managed to remain so well provided with documentary evidence. $\mathrm{He}$ was surely a very well learned man.

F. C. Burkitt.

\title{
ON A PLACE IN ST AUGUSTINE'S RULE.
}

IN the Journal vol. $\mathrm{xx}$ p. 355 , the present writer pointed out that the editor of the Vienna text of St Augustine's Epistulae, the veteran scholar Dr Alois Goldbacher, who at the ripe age of over eighty-four is still active and productive, has altered the reading in one allimportant sentence so that it can no longer be used, as it was by earlier critics, to fix the date at which the Rule was written. Apud Goldbacher, this sentence (Ep. 2 II. 4) now reads:-

cogitate, quid mali sit, ut, cum de deo natis in unitate gaudeamus, interna schismata in monasterio lugeamus.

$$
\text { deo natis] Donatistis m. [ = Ed. Maur ]. }
$$

That Donatistis is right and ought to be restored, it is the alm of this note to shew.

(I) The antithesis in the last two members of this sentence and the emphatic position of interna surely imply that the 'rejoicing in unity' is over those who, though external to the monasterium, were Chrstians before this time, though separate in communion. The rejoicing is caused, not by their conversion, but by their ceasing to be schismatics; 
the phrase 'in unitate gaudere' is employed elsewhere (e.g. Psalm. c. $p$. Don, I 60) over the return of Donatists; unitas itself, much like Catholica, is employed, during the Donatist controversy, in the semitechnical sense of Ecclesia catholica (see Petschenig's Index to C.S..E.L., vol. liii). The sense points then to the Donastists as being the source of the 'rejoicing in unity'; this itself is a weighty argument for Donatistis.

(2) For what can deo natis ${ }^{1}$ here mean? Does it mean 'born of God'? In classical Latin certainly it does; Livy has the very phrase: Deus deo 'natus (i I6. 3). But 'born of God' as Scripture is not Deo natus, but either natus ex Deo ('́) or natus de Deo (see Sabatièr ad locc)..$^{2}$ If Augustine here means 'converts', he has employed an unscriptural and unusual phrase: he very seldom (never, I might almost say) employs a bare ablative after nasci. Can Deo here be dative? Consider one or two analogous datives.

Nasci with dative is employed throughout all Latin in the sense 'born to, destıned for': TERT. de paenit., last sentence: nec ulli rei nisi paenitentiae natus; CARM. DE IONA PROPH. 3 solis oculis nascentia poma. Commodian Instr. 2. Io. 7 is different: in aluo recurrant nascanturque quasi denuo suae matri de uentre. Mori peciato (peccatis, legi) (dative) is Scriptural, and supplies such parallels as saeculo mori (e. g. to name only one or two that are at hand, Ps.-Hier. Ep. r9. I 5 init ; 19. 20 non nos mundo, sed mundus nobis mortuus est; 'An Ancient Homiliary' in Journal xvi (1914) p. 317 mortuus saeculo and mortuus mundo $)^{3}$; TERT. Resurr. Carn. xix has homo mortuus Deo. Viuere Deo (dative) is Scriptural, and frequent (Avg. In Ioan. Eu. 26: I3 uiuat Deo de Deo; Pavl. Nol. Carm. in Ep. 7 , line 107 uiue, precor, sed uiue Deo)(uiuere mundo, cf. Ep. 23. 21). Such phrases as these - were soon paralleled: TERT. Resurr. Carn., ut supra, has redanimatus et reuiuificatus Deo; Ps.-Hier. Ep. 27. I (P. L. xxx $223 \mathrm{~A}, \mathrm{~B})$ has an interesting collection: perire sibi existimans (diabolus) quidquid Christo saluatur, et mori Synagogae suae quidquid Ecclesiae uinificatur. In Augustine the following datives are analogous: Conf. I2.1 I4. I 7 sic amo eos occidi sibi ut uiuant Tibi; In Ioan. Eu. 60. 3 timeat ne pereant homines Christo, contristetur cum perit aliquis Christo; . . timeat et sibi ne pereat Christo; C. Gaud. 2. 4. 4 perire quemquam Christo, and with the uncommon word repuerasco: ab his ad seipsam colligat (anima) et repuerascat Deo, Quant. An. 28.55 .

But does Augustine employ nasi with the dative? In the MS

1 The de is to be taken, of course, with gandeamus, as e.g. in the refrain of the Psalmus: omnes qui gaudetis de pace....

2 Pontius Vtt. Cypr. 2. I has nalus Deo, but it is not easy to say whether Deo is ablative or dative; probably it is abl, the ex being omitted for euphony after exquo.

3 Cf. Aug. Ep. ro. 3 amori corporeo animus montur. 
Concordance to St Augustine ${ }^{2}$ prepared by the great P. Odilo Rottmanner, O.S.B., I find two examples, to which I can add only one :-

Pect. Mer. ii 24. $3^{8}$ ut Deo nascerentur ex Deo, qui prius nati fuerant ex carne saeculo. (vid. sqq.)

C. Iul. vi 2. 4 propter quod [sc. peccatum] omnis homo prius mundo, non Deo nascitur, et ut Deo nascatur, de mundo eligitur...

Nupt. et Concup. i I9. 2 I mundo, non Deo nascitur; Deo autem nascitur cum ex aqua et spiritu renascitur.

These examples, all I know in Augustine, shew clearly that when Augustine does use Deo nasci (dative), he employs it in a context which prevents all obscurity, and in apposition with mundo (et sim.). We may conclude that, while Deo nasci is Augustinian, neither the first reason advanced nor this second allows it the place Goldbacher has given it in this sentence of the Rule.

Non otiose, as St Ambrose says so often, have I put forward this grammatical discussion: it serves to introduce a more weighty matter, namely, another point of view of Regeneration. . The dative with nasci carries further the often-quoted fecisti nos ad $T_{e}$ (Conf. r. I) and illustrates his frequent Deo adhaerere, inhaerere. Regeneration has not only God as source $(e x D e o)$ but God as aim and end : we are born again to or unto God, a fact borne out by experience. A regenerate (if the word may be used) is usually less conscious of God as the source of his new-found life, than of the God he has discovered as Friend.

To sum up, the reasons given above are unanimous in recommending the restitution of the Maurist Donatistis, which Goldbacher ejected on the testimony of his manuscripts. The earliest of these, for this introductory section, is thirteenth-century, so their authority need not count much against reason. If Donatistis was given by the archetype, as seems certain, the omission of the second group of similar letters (Dona-tis-tis) easily explains the corruption. A similar error occurs in De Baptismo iii I. I (p. 197. I Petschenig): pro Donatistis esse proponendam, where L (Sangall. ${ }_{5} 8$, saec. ix) gives Donatis.

J. H. BAXter.

P.S.-Since writing, I have come upon several similar datives, of which the most interesting is Ps-Avg. Hypomn. i 2.3 Deo dormiunt quos diabolus perisse putabat.

1 The use of which I owe to the kındness of Abt Bonifaz Woehrmueller, O.S.B., of Munich, who has put it into my hands for combining with my own large collections into a vast Augustinian Index Rerum et Verborum, which, helped by Professor Souter's exten'sive lexicographical collections durnng a quarter-century, will some day, I hope, see the light. Meantime I shall be glad, as will Dr Souter, to consult our respective collections for any scholar interested. 